\title{
Inhibition of breast tumor growth and abnormal angiogenesis in mice treated with endothelial cells and their progenitor mesenchymal stem cells derived from bone marrow
}

\author{
M. ADELIPOUR ${ }^{1}$, A. ALLAMEH ${ }^{1, \star}$, S. M. TAVANGAR ${ }^{2}$, Z. M. HASSAN ${ }^{3}$, M. SOLEIMANI $^{4}$
}

${ }^{1}$ Department of Clinical Biochemistry, Faculty of Medical Sciences, Tarbiat Modares University, Tehran, Iran; ${ }^{2}$ Department of Pathology, Shariati Hospital, Tehran University of Medical Sciences, Tehran, Iran; ${ }^{3}$ Department of Immunology, Faculty of Medical Sciences, Tarbiat Modares University, Tehran, Iran; ${ }^{4}$ Department of Hematology, Faculty of Medical Sciences, Tarbiat Modares University, Tehran, Iran

*Correspondence: allameha@modares.ac.ir

Received April 7, 2016 / Accepted July 18, 2016

\begin{abstract}
Incorporation of endothelial cells or their progenitor cells into newly sprouting blood vessels can contribute to tissue vascularization after ischemic injury. However, the interaction of the stem cells-derived endothelial cells with angiogenesis within tumors is not well understood. The aim of this study was to examine the efficiency of endothelial-like cells derived from MSCs in controlling breast tumor growth associated with abnormal angiogenesis. For this purpose, Balb/c mouse model of breast carcinoma was developed and subjected to intra tumor (I.T)/intra venous (I.V) therapy with undifferentiated MSCs or endothelial cells derived from them. The homing of the stem cells was approved by measuring different markers as well as tracing green fluorescence protein (GFP)-labeled MSCs in the tumors. Tumor growth was measured following cell therapy using a digital caliper. At the end of treatment period (30 days) the angiogenesis markers; VEGFR2 expression as well as micro-vessel density (MVD) using CD31 were estimated in tumor tissues. Stem cell transplantation to mice bearing breast tumors resulted in tumor growth suppression in all experimental groups. The endothelial markers; CD31 and VEGFR2 were down regulated following I.T delivery of the endothelial cells. Accordingly, angiogenesis was suppressed following I.T administration of endothelial cells which was associated with increased focal necrosis in the tumors. In conclusion, data show that endothelial cells directly injected into tumors is more efficient compared to undifferentiated MSCs in controlling tumor-associated angiogenesis and tumor growth.
\end{abstract}

Key words: angiogenesis, breast carcinoma, endothelial markers, micro vessel density, stem cell therapy

Angiogenesis is one of the hallmarks of cancer that is considered as a target for treating solid tumors [1]. Tumor-associated angiogenesis which often occurs during carcinogenesis process can stimulate abnormal cell proliferation by providing a supply of essential oxygen and nutrients [2]. The vessel abnormality has been characterized by hyperactive vessel growth, heterogeneous distribution, tortuosity, dilation, large gaps between endothelial cells and lack of pericyte coverage that created insufficient leaky vessels. The abnormal vascular network lead to some consequences in tumor microenvironment such as hypoxia, acidity and high interstitial fluid pressure that cause the selection of more malignant cancer cells for proliferation and facilitation of metastasis [3-6].

The vessel network in tumor tissues is often identified by endothelial specific markers such as; Vascular Endothelial
Growth Factor Receptors (VEGFRs), Von Willebrand Factor (vWF), factor-VIII, CD34 and CD31 [7-9]. It has been reported that vascular density of human breast cancer is increasing which is associated with CD105 and tumor progression [10]. In this connection, anti-angiogenesis therapy using avastin combined with oleamide as a gap junction inhibitor has been shown to suppress invasion and metastasis of cancer in a xenograft murine model of breast cancer [11]. Application of a combined treatment of murine breast cancer model with adenovirus vectors expressing angiostatin and IL-12 in suppression of tumor also indicated the role of angiogenesis in cancer growth [12].

Cancer therapy by inhibitors of angiogenesis such as Bevacizumab (monoclonal antibody against the VEGF-A ligand), Aflibercept (soluble VEGF receptors) and sunitinib (Tyrosin 
kinase receptor inhibitors) are currently used as effective drugs in controlling angiogenesis in some cancers [13-15]. The clinical trial of various drugs including antibodies for targeting angiogenesis in breast cancer has been reviewed by Mackey et al. (2012). The outcome of using anti-angiogenic agents (Sorafenib and Pazopanib) in combination with chemotherapy or targeted therapy in breast cancer showed improved response rate and progression-free survival but no overall survival advantage [16].

Recently, functional nanobody against VEGFR2 has been produced and characterized for the blockade of VEGFR2 signaling and suggesting its use in breast cancer treatment [17].

There are controversies over the use of cell therapy particularly, stromal cell therapy for breast cancer treatment [18-20]. Different preparations of MSCs have been used for treatment of diseases such as strokes [21, 22], diabetes $[23,24]$, hematopoietic and immune system disorders [25] and neurodegenerative diseases [26]. The anti-tumor effects of MSCs derived from umbilical cord blood (UCB) in a mouse model of breast cancer has also been reported [19]. Likewise, the therapeutic potential of endothelial progenitor cells (EPCs) has worked out in treatment of ischemic tissues via vasculogenesis. Transplantation of large-EPCs has been reported to enhance vascularization in a murine model of hindlimb ischemia [27]. MSCs and EPCs were used for tissue regeneration in experimental renal artery stenosis model of pig and showed that both cells result in decrease of injury [28].

Earlier we showed that the MSCs prepared from human bone marrow can readily be differentiated into functional endothelial cells expressing morphological and molecular markers of angiogenesis [29]. Transplantation of endothelial cells at early stage of differentiation into the groin region of the severe combined immunodeficiency (SCID) mouse model contributed to neo-vascularization [30]. In this connection, Otsu and co-workers showed that intra-tumor (I.T) administration of MSCs differentiated from mice bone marrow at high concentration to mice bearing melanoma possessed effective antiangiogenic and cytotoxic effects [31]. However, to our knowledge there are no reports on direct targeting of tumor-associated angiogenesis by endothelial cells or their progenitor stromal cells.

The question rises whether transplantation of endothelial cells derived from stromal cells can induce or inhibit the tumor-associated angiogenesis. To answer this question in present study, a mouse model of breast cancer with abnormal vessel network was developed which was targeted (I.T or I.V) with either endothelial-like cells or their progenitor MSCs. MSCs differentiated to endothelial cells were used to improve the efficiency of cell therapy protocols aiming to angiogenesis control. The performance of stem cells to target angiogenesis process was evaluated by changes in tumor growth as well as angiogenesis markers viz. VEGFR2 and CD31.

\section{Materials and methods}

Chemicals and reagents. Dulbecco's- modified Eagle's Medium (DMEM), Roswell Park Memorial Institute medium (RPMI), fetal bovine serum (FBS) and phosphate-buffered saline (PBS) were from Gibco (USA). Penicillin Streptomycin (Pen Strep) and Trypsin-EDTA were from Bio-idea (Iran). Vascular endothelial growth factor (VEGF) and Insulin-like growth factor 1(IGF1) were from Peprotech (USA). Oil Red $\mathrm{O}$, Alizarin Red S and 40,6-diamidino-2-phenylindole (DAPI) were from Sigma (USA). Anti-CD105: (cat.E01420-1630), Anti- CD29: (cat.12-0291-81) and Anti-CD34: (cat.11-0341) antibodies were from eBioscience (USA). Anti-CD45: (cat. ab10558), Anti-GFP antibody: (cat.ab1218), Goat anti-Rabbit secondry antibody: (cat.ab6717) and Goat anti-Rat IgG H\&L (PE) secondary antibody: (ab7010) were the products of Abcam (UK). Anti VEGFR2: (cat.561052) was from BD Bioscience (USA). Anti-VCAM-1: (sc-19982) and Anti-CD31: (sc-1506) were from Santa Cruz (USA). Polyclonal Goat Anti-Rabbit Immunoglobulins/HRP: (P 0448) was from Dako (USA). RNA Extraction Kit (Gene All Hybrid-R) and cDNA Synthesis Kit (HyperScript RT premix) were from Gene all (South Korea). Taq DNA Polymerase 2x Master Mix Red and Real Q Plus 2x Master Mix Green Low ROX were the products of Ampliqon (Denmark).

Animals and treatments. In this experiment 60 inbred female Balb/c 6 weeks old mice weighing 15-17 g were used to induce isogenic experimental model of breast cancer. The mice were purchased from the Pasteur Institute of Iran and transferred to the animal house of Tarbiat Modares University at least one week before starting the experiment. The mice were kept in standard cages (10 mice in one cage) in standard condition on a $12 \mathrm{~h}$ light/dark cycle and the room temperature was adjusted between $21-23^{\circ} \mathrm{C}$. The animals have free access to water and food. This study was approved by ethical Committee of Tarbiat Modares University.

Preparation of breast tumor tissue. In this experiment 4 female Balb/c mice were transplanted with $4 \mathrm{~T} 1$ cell line. After the development of breast cancer, the tumors were confirmed by pathologist as nuclear pleomorphism, high mitotic index and severe N/C ratio. After one week tumors were surgically removed and fresh tumors were used for grafting to the groups of mice in order to induce breast carcinoma.

Induction of experimental model of breast cancer. In this experiment 60 inbred female $\mathrm{Balb} / \mathrm{c}$ mice were randomly selected and divided in six groups for different treatments. To induce breast cancer in mice, each mouse was slightly anesthetized by injecting an I.P dose of $25 \mu \mathrm{l} / \mathrm{g}$ of a mixture of ketamin $10 \%$ and xylazin $2 \%$. A subcutaneous pocket created by blunt dissection in the left flank region which was used for transplantation of fresh breast tumor biopsy $(2-3 \mathrm{~mm})$ originated from $4 \mathrm{~T} 1$ cell line (as described above). The mice were examined everyday for possible tumor development. The first sign of tumor formation was noticed one week after transplantation in all the experimental groups. This observa- 
tion was confirmed by showing the growth of the initially grafted tissue at the site of transplantation [32].

The mice bearing tumors of approximately $5-7 \mathrm{~mm}$ in diameter were the candidates of cell therapy. Each mice was treated either with intratumor (I.T) or intravenous (I.V) of MSCs or endothelial-like cell suspension $\left(1.5 \times 10^{6}\right.$ cells in $100 \mu \mathrm{l}$ of PBS).

The mice were divided into six groups (10 mice in each group) and treated as follows:

Group-1 mice transplanted with tumor tissue in the left flank injected I.T with PBS only as positive control (PBS/I.T).

Group-2 mice bearing tumors treated with I.T administration of undifferentiated MSCs (MSC/I.T).

Group-3 mice bearing tumors treated with I.T administration of endothelial-like cells (EC/I.T).

Group-4 mice transplanted with tumor tissue in the left flank injected I.V with PBS only as positive control (PBS/I.V).

Group-5 mice bearing tumors treated with I.V administration of undifferentiated MSCs (MSC/I.V).

Group-6 mice bearing tumors treated with I.V administration of endothelial-like cells (EC/I.V).

During the 30-days experiment the animals were examined for their weight gain and changes in tumor size. Tumor size was measured using a digital caliper. Then at the end of the experimental period, all the animals were sacrificed by cervical dislocation and tumor tissues were removed and processed for histopathological and molecular studies.

Isolation of MSCs from mouse bone marrow. MSCs were routinely isolated from the femur and tibia of $\mathrm{Balb} / \mathrm{c}$ mouse following the procedure described previously [33]. The cells were cultured in DMEM supplemented with $10 \%$ FBS and $1 \%$ streptomycin at $37^{\circ} \mathrm{C}$ in $\mathrm{CO} 2$ incubator (5\% CO2). The culture medium was changed with fresh medium every 3 days and the cell passage was done when they reached $80 \%$ confluence.

Characterization of MSCs. Isolated MSCs were characterized by identification of their surface markers as well as their differentiation potential into adipogenic and osteogenic lineages. Expression of selected markers on MSCs namely; CD29, CD105 and CD45 were determined by flow cytometry (Applied Biosystems, USA). Briefly, the cells were detached using trypsin-EDTA $(0.25 \%)$ and suspended in PBS $\left(10^{5}\right.$ cells/100 $\mu \mathrm{l})$ before adding each specific antibody and then incubated for 1 hour at $4^{\circ} \mathrm{C}$. The cells were then washed with PBS and subjected to flow cytometry for cell counting.

Differentiation potential of MSCs. The differential potential of the MSCs (P4-P6) isolated from mouse bone marrow was examined by subjecting the cells to differentiation into adipocytes and osteocytes as described previously [34]. Adipogenic differentiation was performed in DMEM supplemented with $10 \% \mathrm{FBS}$, dexamethasone $\left(10^{-6} \mathrm{M}\right.$ or 1000 $\mathrm{nM})$ and ascorbic acid $(50 \mu \mathrm{g} / \mathrm{ml})$ for 14 days at $37^{\circ} \mathrm{C}$ in $\mathrm{CO}_{2}$ incubator $(5 \% \mathrm{CO} 2)$. Formation of adipocytes was confirmed by observing oil droplets in the adipocytes by staining the cells with Oil Red.

Besides, osteogenic differentiation was performed in DMEM supplemented with $10 \%$ FBS, dexamethasone $\left(10^{-8}\right.$ M or $10 \mathrm{nM}), \beta$-glycerol phosphate ( $10 \mathrm{mM}$ ) and ascorbic acid $(50 \mu \mathrm{g} / \mathrm{ml})$ for 21 days at $37^{\circ} \mathrm{C}$ in a $\mathrm{CO}_{2}$ incubator adjusted with 5\% CO2. Formation of hydroxyl apatite crystals as an index of osteoblast formation was confirmed by staining the cells with Alizarin Red.

Differentiation of MSCs into endothelial-like cells. Differentiation of MSCs (P4-P6) into endothelial cells was induced in DMEM and RPMI (1:1) supplemented with 5\% FBS, VEGF (50 ng/ml) and IGF1 (20 ng/ml) for 5 days in $\mathrm{CO} 2$ incubator at $37^{\circ} \mathrm{C}$ and $5 \% \mathrm{CO}_{2}$. The endothelial markers such as cellular VEGFR2, CD34 and VCAM1 were detected using flow cytometry. These endothelial-specific markers were estimated on day 5 of differentiation process. In this assay anti-VEGFR2, anti-CD34 and anti-VCAM1 antibodies were used to estimate VEGFR2, CD34 and VCAM1 respectively.

Labeling MSCs with lentiviral vector carrying GFP gene. For lentiviral production, HEK293T cells (70-80\% confluent) were transfected with three plasmids (psPAX2, pMD2G, pLenti-III-PGK-GFP) using Ca-PO4 precipitation method as described previously [35]. The culture supernatant containing lentiviral particles were collected and concentrated by polyethylene glycol (PEG)- $\mathrm{NaCl}$. The transfection of lentiviral vector to HEK293T cells was confirmed by fluorescent microscope for the expression of GFP.

MSCs (50-70\% confluent) were transduced by lentiviruses in presence of $8 \mu \mathrm{g} / \mathrm{mL}$ polybrene for $24 \mathrm{~h}$ in order to increase the efficiency of transduction. The transduced MSCs by lentiviral vector were verified by showing GFP signals under fluorescent microscope. Then, MSCs expressing GFP were selected with puromycin $(1.5 \mathrm{mg} / \mathrm{ml})$ for 14 days [35].

Administration of GFP-labeled MSCs for assessment of cell migration and homing into tumors. In this experiment two groups of mice bearing breast cancer were injected either with I.T or I.V route of MSCs labeled with GFP. The number of cells injected to each mouse was approximately $1.5 \times 10^{6}$ cells prepared in $100 \mu \mathrm{l}$ PBS. One week after injection, animals were sacrificed by cervical dislocation, tumors were surgically removed. From each tumor 2-3 small portions were processed for preparation of paraffin embedded blocks. From each block serial sections $(4 \mu \mathrm{m})$ were prepared using microtome tool. The sections were subjected to Immunohistochemistry (IHC) using anti-GFP antibody (1:100). The GFP-labeled MSCs were traced under fluorescent microscope. IHC performed on tumor preparations from mice treated under similar condition but untreated with stromal cells were considered as control.

Measurement of tumor size and Relative Tumor Volume (RTV). During the stromal cell therapy, tumor growth was monitored in all the experimental groups. Tumor size was recorded daily using a digital caliper and presented as RTV that was calculated using the following formula: 

[32]

$\mathrm{V}\left(\mathrm{mm}^{3}\right)=\pi \mathrm{ab}^{2} / 6(\mathrm{a}=$ length of tumor, $\mathrm{b}=$ width of tumor $)$

$\mathrm{RTV}=\mathrm{TV}_{\mathrm{n}} / \mathrm{TV}_{0}$

$\mathrm{V}$ : Volume

RTV: Relative Tumor Volume

$\mathrm{TV}_{\mathrm{n}}$ : Tumor Volume day

$\mathrm{TV}_{0}$ : Tumor Volume day

$\mathrm{T} / \mathrm{C} \%=$ (mean RTV of treated group)/(mean RTV of control group) $\times 100$

Percentage tumor growth inhibition $=100-(\mathrm{T} / \mathrm{C} \%)[36]$

The effects of stromal cell therapy on tumor growth in treated groups were determined in relation to the RTV determined in control groups. The median RTV determined in control group was considered as $100 \%$.

Histopathology of tumors. Tumor biopsies obtained from each mouse were fixed in aqueous formaldehyde (10\%) and processed for $\mathrm{H} \& \mathrm{E}$ staining. The sections were examined for pathological characterization by pathologist. For calculation of focal necrosis 10 selected fields were observed by pathologist under light microscope (magnification $x 400$ ). The following scoring numbers were given to each sample: 0 (without necrosis), +1 (less than $10 \%),+2(10 \%-40 \%)$ and $+3(>40 \%)$. In a similar manner the extent of hemorrhage in tumor was calculated in selected fields. The sections were also examined for vascular invasion indicating the presence of tumor cells in the blood vessels.

CD31 detection by immunohistochemistry. In this experiment the Micro Vessel Density (MVD) technique was used to estimate CD31 expression on the endothelial cells in tumor tissues. CD31 in tumor tissue preparations was estimated by IHC using anti-CD31 antibody. This assay was performed on 4-5 $\mu \mathrm{M}$ sections prepared from the paraffin embedded tumor tissues, thereafter stained with anti-CD31 antibody labeled with HRP according to the manufacturer's instructions.

The number of microvessels in the tissue preparation was observed under light microscope using 40x lens (400x magnification) and the vessels were counted in selected fields known as "hot spot" areas. This technique could discriminate darkly stained endothelial cells or cell clusters appearing as a single vessel with those of necrotic cells (originated from immunoreactive cells) [37].

Expression of VEGFR2 in tumor tissues. Expression of VEGFR2 as an endothelial marker was measured in breast tumors prepared from different experimental groups. VEGFR2-specific mRNA was determined by Real Time PCR (QPCR) in Real-Time PCR System (Applied Biosystems 7500,

Table 1. The sequence of primers used in QPCR.

\begin{tabular}{ll}
\hline Gene & Primer sequence \\
\hline VEGFR2 Forward $\left(5^{c} \rightarrow 3^{c}\right)$ & TGCCTACCTCACCTGTTT \\
VEGFR2 Reverse $\left(5^{c} \rightarrow 3^{c}\right)$ & CACTTTTACTTCTGGTTCCT \\
HPRT Forward $\left(5^{c} \rightarrow 3^{c}\right)$ & ATTATGCCGAGGATTTGGA \\
HPR Reverse $\left(5^{c} \rightarrow 3^{c}\right)$ & ACTTATAGCCCCCCTTGA \\
\hline
\end{tabular}

USA). For this, total RNA was extracted from all the tumor tissues using RNA extraction kit following the manufacturer's protocol. cDNA was synthesized from mRNA using cDNA synthesis kit according to manufacturer's protocol. A pair of specific primers was designed using CLC software. The sequences of primers used in this assay are as indicated in Table 1. The PCR reaction was optimized for annealing temperature and primer concentration. Gene amplification was performed in $0.2 \mu \mathrm{l}$ volume microtube in ABI7500 real-time PCR. The reaction mixture contained $4 \mu$ of diluted cDNA, 5 pmol of each primer, $10 \mu \mathrm{l}$ of $2 \mathrm{x}$ SYBR green master mixes in a total volume of $20 \mu \mathrm{l}$.

The PCR protocol was carried out as follows; initial step of $95^{\circ} \mathrm{C}$ for $15 \mathrm{~min}$, amplification step of 40 cycles started with $15 \mathrm{sec}$ at $95^{\circ} \mathrm{C}$ followed by $1 \mathrm{~min}$ at $58^{\circ} \mathrm{C}$. This program was followed by analysis of melting curve that was performed with linear heating from $60-90^{\circ} \mathrm{C}$.

Under similar condition the PCR assay was performed with HPRT as a house keeping gene using specific primers (Table 1) and considered as internal control. The fold change of VEGFR2 in tumor tissues calculated according to following formula:

Delta $\mathrm{Ct}=\mathrm{Ct}_{\text {VEGFR2 }}-\mathrm{Ct}_{\mathrm{HPRT}}$

Delta Delta $\mathrm{Ct}=\Delta \mathrm{Ct} \mathrm{treated}_{\text {tre }}-\Delta \mathrm{Ct}$

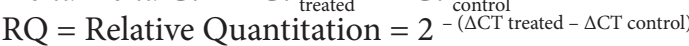

Statistical analysis. In this study, the data were analyzed by SPSS version 16. The Kolmogorov-Smirnov test was used to find the distribution of data. One-way ANOVA followed by Tukey's test was used to compare RTV or MVD among all the experimental groups. The significance level was considered at $\mathrm{p} \leq 0.05$.

\section{Results}

Characterization of MSCs. MSCs isolated from mouse bone marrow were characterized by two approaches; first by showing expression of specific CD markers on the cell surface, also by evaluation of their differential potential to other cell lineages. As shown in Figure 1A flow cytometry data showed that the MSCs are positive for CD29 and CD105. This was further confirmed by showing that the cells are negative for CD45 which is a hematopoietic stromal cell marker. Furthermore, it was demonstrated that the MSCs possess the ability to differentiate into osteoblasts and adipocytes. As shown in Figure 1B, under the specific conditions the MSCs could differentiate into osteoblasts and adipocytes which were identified by alizarin red and oil-red O-staining respectively.

Differentiation of MSCs into endothelial like-cells. As shown in Figure 2, three specific markers were used to characterize endothelial differentiation of MSCs under the experimental condition using selected culture media. The endothelial cells obtained on day 5 of differentiation were positive for VEGFR2, VCAM1 and CD34. Approximately $60 \%$ of the endothelial-like cells were positive for VEGFR2 markers, however VCAM1 and CD34 were expressed in about $30 \%$ of the cells. 

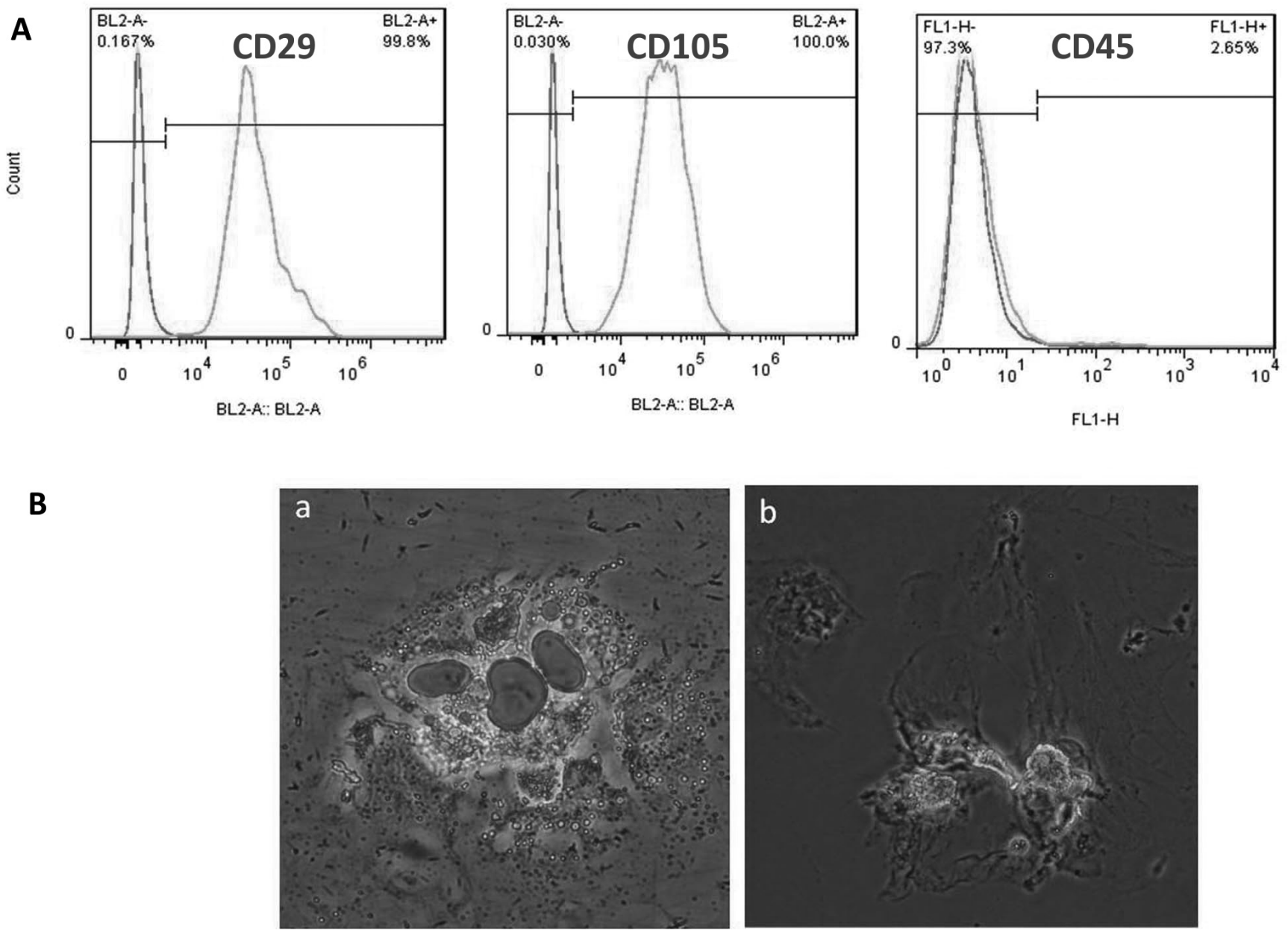

Figure 1. Characterization of mesenchymal stromal cells: A) Flow cytometric analysis of cell surface markers of mesenchymal stromal cells. Data show the presence of CD29 and CD105 and absence of CD45 on the cell surface. B) The differentiation potential of mesenchymal stromal cells to adipocyte and osteoblasts. Details about the differentiation condition are as described in 'Methods' section. Section a: shows the presence of lipid droplets in differentiated adipocytes stained with oil-red (300x); And section b: shows calcium deposits in differentiated osteoblasts stained by alizarin red (100x)..

Incorporation of MSCs transduced with GFP into tumor tissue. As shown in Figure 3, almost all the MSCs were transduced with lentivirus carrying GFP gene. Administration of GFP-labeled cells into mice either with I.T or I.V showed incorporation of the cells into breast tumors. The labeled cells were traced by IHC assay using anti GFP antibody in tumor tissue. It was demonstrated that the GFP-labeled cells were present in tumor regardless of the route of administration (Figure 4).

Effect of stromal cell therapy on tumor growth. Comparison of tumor growth in different experimental groups of mice showed that the stem cell injected by either I.V or I.T caused a significant decrease $(\mathrm{P}<0.05)$ in tumor growth (Figure 5). Regardless of the route of administration, the RTV estimated in control groups was always higher than that measured in treated animals. The RTV in mice treated I.T with MSCs was $65.6 \%$ (34.4\% inhibition) of that measured in respective con- trols $(\mathrm{P}<0.005)$. Mice treated I.T with endothelial cells at their early stage of differentiation showed a maximum inhibition in tumor growth $(53.4 \%$ inhibition; $\mathrm{P}<0.005)$.

The tumor growth in mice treated I.V with MSCs was $71.5 \%$ of that measured in corresponding controls (28.5\% inhibition; $\mathrm{P}<0.05)$. Whereas, the rate of in case of animals treated I.V with endothelial-like cells the tumor growth was reduced to more than $50 \%$ compared to respective controls ( $46.3 \%$ inhibition; $\mathrm{P}<0.05$ ). A representative image of tumors dissected from stem celltreated mice (smaller size) and a relatively larger tumor that was obtained from mice untreated with stem cells (Figure 5D).

Effects of stromal cell therapy on histology of breast tumor. Stromal cell therapy of the breast cancer in the animal model resulted in changes in breast histology. As shown in Figure 6 and Table 2 malignant cells characterized with pleomorphism, high mitotic index and severe N/C ratio were present in tumors. The tumors in untreated mice (positive 

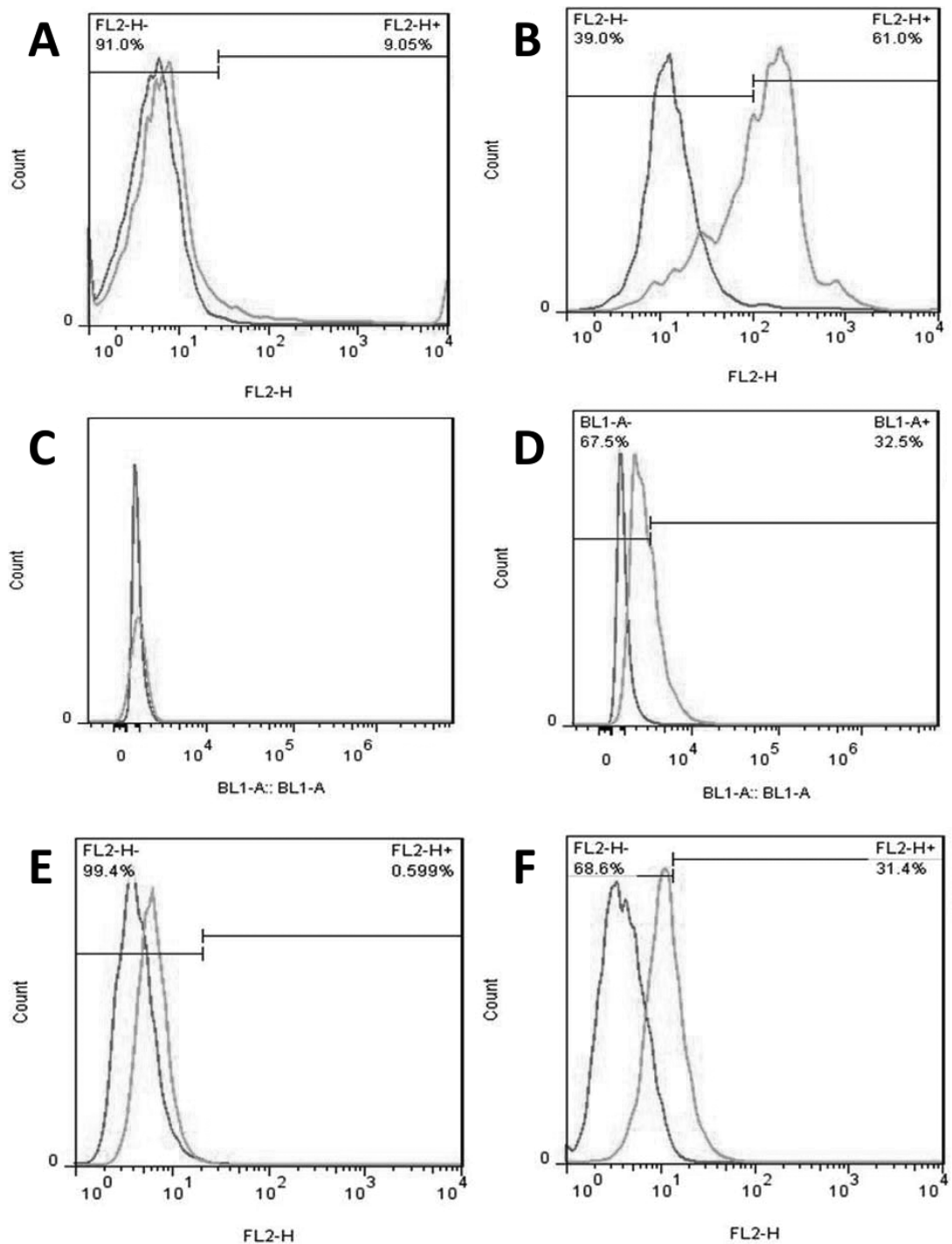

Figure 2. Flow cytometry data of endothelial markers in endothelial-like cells differentiated from mesenchymal stromal cells: Details about the endothelial differentiation are as described in methods section. Representative graphs show endothelial markers in the cells. Section A) VEGFR2 expression in MSCs; B) VEGFR2 expression in endothelial cells; C) Flow cytometric analysis of CD34 showed the no expression of CD34 in MSCs; D) CD34 expression in endothelial cells; E) VCAM1 expression in MSCs; F) VCAM1 expression in endothelial cells. \% indicated the percentage of cells expressing respective markers.
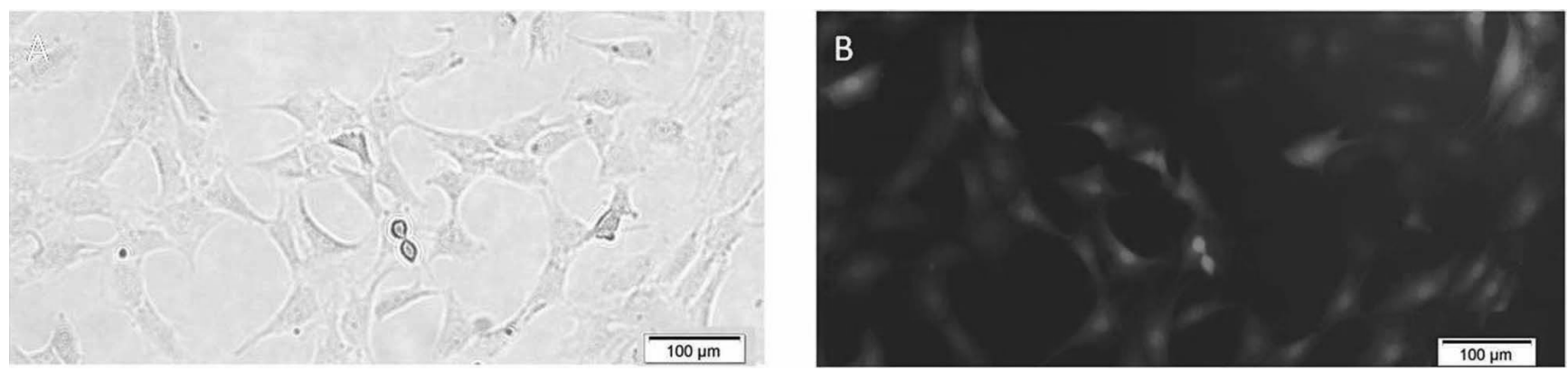

Figure 3. Mesenchymal stromal cells labeled with lentiviral vector carrying green fluorescence protein (GFP): A) Optical microscopy and B) fluorescent microscopy. Original magnification is 100x. 

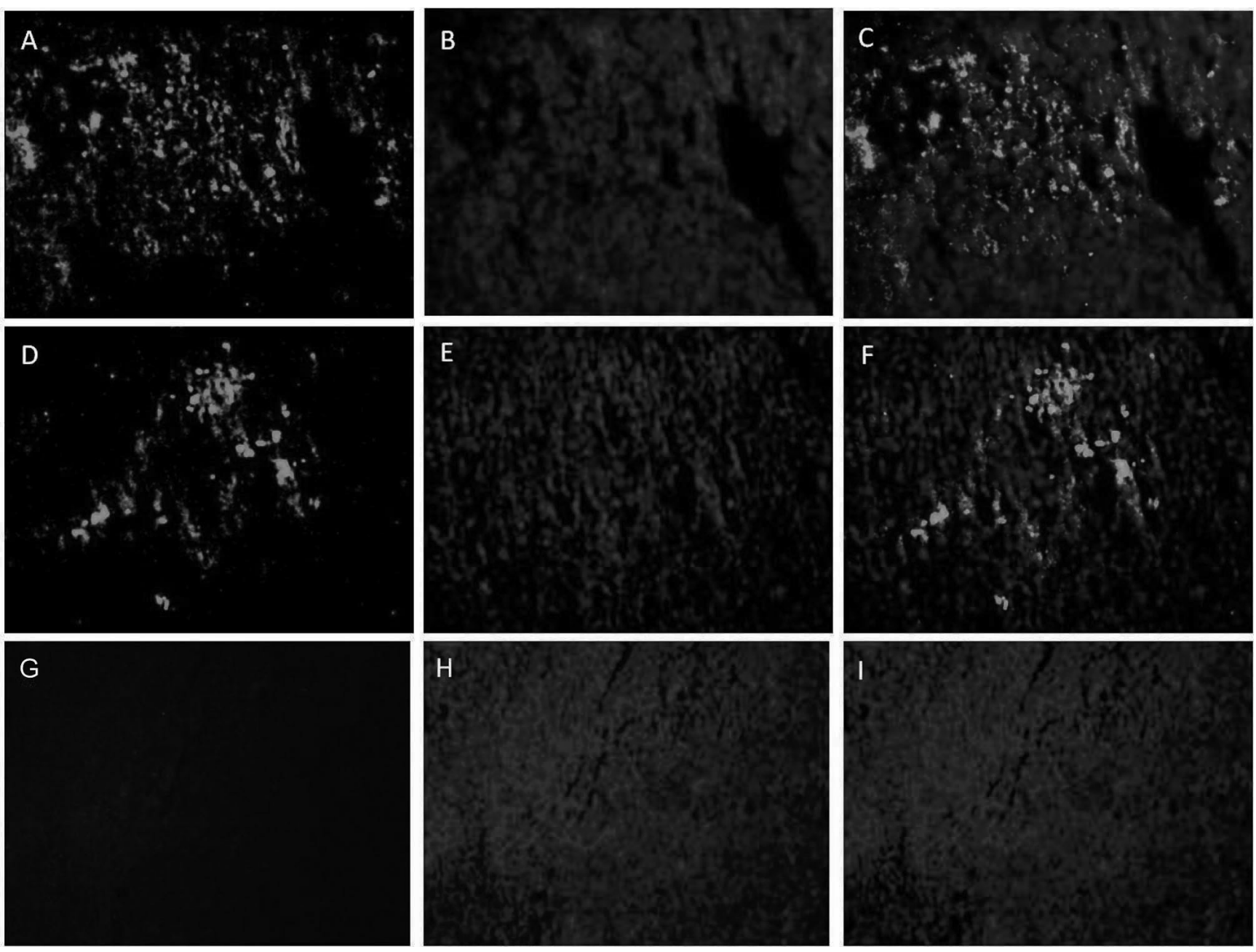

Figure 4. Tracing mesenchymal stromal cells labeled with green fluorescence protein in breast tumors: Experimental details are as described in method section. MSCs penetrated into tumors are observed as green fluorescence. The cell nuclei stained with DAPI are in blue color.

Photomicrographs A-C show breast tumors prepared from mice injected I.T with MSCs labeled with GFP. Photomicrographs D-F show MSCs labeled with GFP in breast tumor in mice treated I.V. Sections G-I breast tumor preparations of untreated mice stained with IHC using anti-GFP antibody. Original magnification is 200x.

control) were observed to be associated with vascular invasion and low focal necrosis (Figure 6).

Intra-tumor (I.T) administration of MSCs derived from bone marrow resulted in an increase in focal necrosis as well as increased local hemorrhage compared to control group.

Comparison of focal necrosis and hemorrhage of breast tissue in different experimental groups processed by H\&E staining showed a remarkable increase in tumor necrosis and hemorrhage in mice treated I.T with endothelial cells at their early stage of their differentiation. The focal necrosis and hemorrhage in tumors from mice injected I.V with MSCs or endothelial cells (day 5) was relatively higher than that observed in tumors from animals untreated with stem cells (Table 2).

Effects of cell therapy on micro vessel density (MVD) of breast tissue. In this experiment, the CD31 was considered as a specific marker for MVD. CD31 was highly expressed in untreated tumor tissue as shown in IHC analysis. As shown in Figure 7, the average of hot spots detected in the PBS/I.T group and in the PBS/I.V group was found to be 11.6 and $12.2 / \mathrm{mm}^{2}$ respectively. I.T administration of MSCs or endothelial cells at their early stage of differentiation significantly decrease the MVD in breast tumor compared to respective control (5.8/ $\mathrm{mm}^{2}$ or $4.4 / \mathrm{mm}^{2}$ ). As shown in Figure 7, expression of CD31 in mice treated I.V with MSCs or endothelial-like cells was lower than that measured in respective control group $\left(6.4 / \mathrm{mm}^{2}\right.$ and $10 / \mathrm{mm}^{2}$ respectively).

Expression of VEGFR2 in breast tumors in mice treated with stem cells. VEGFR2 was estimated by QPCR using VEGFR2-specific mRNA and reported as mean RQ with standard deviation. As shown in Figure 8 the mice bearing 
A

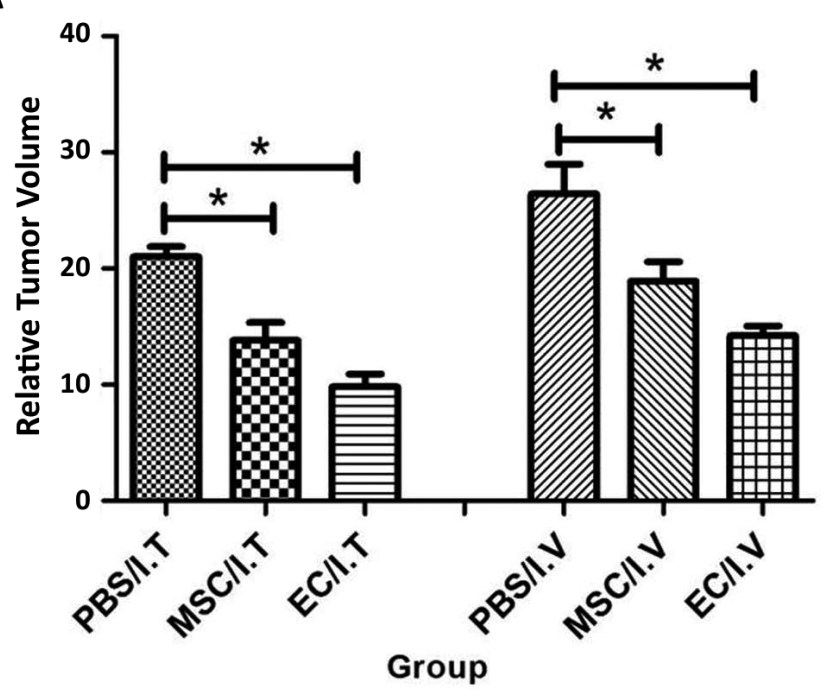

D

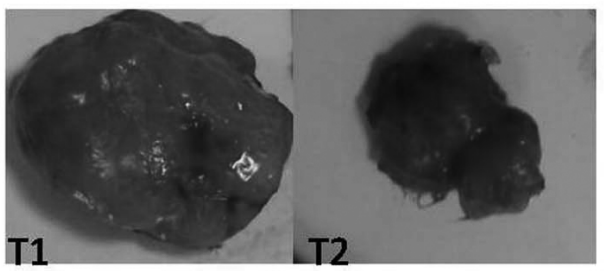

B

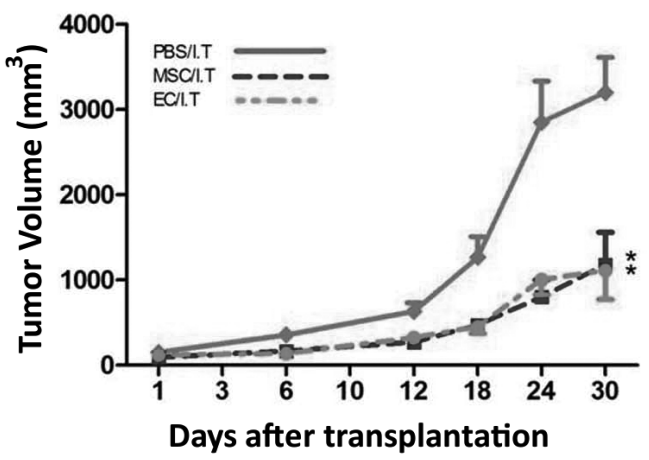

C

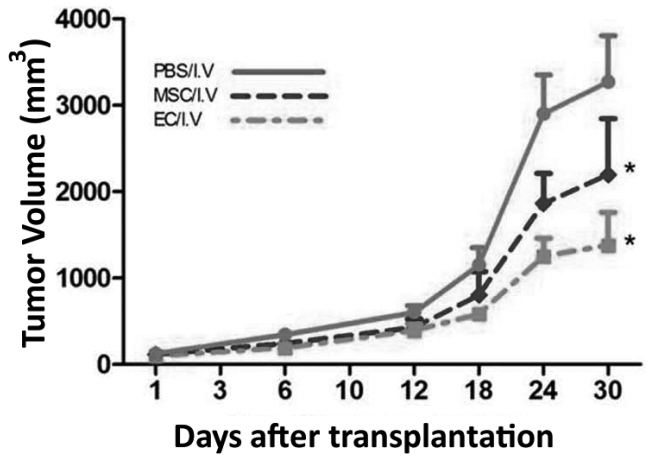

Figure 5. Suppression of breast tumor growth in mice model treated with stem cells: A) Experimental details are as described in method section. The relative tumor volume (RTV) was calculated from the tumor size which was measured by a digital caliper. PBS/I.T: Mice bearing breast tumors without stromal cell therapy (PBS treated by intra tumor route). MSC/I.T: Mice bearing breast tumors treated with MSCs by intra tumor route. EC/I.T: Mice with breast tumor treated with endothelial cells by intra tumor route. PBS/I.V: Mice bearing breast tumors without stromal cell therapy (PBS treated by intra venous route). MSC/I.V: Mice bearing breast tumor treated with MSCs by intravenous route. EC/I.V: Mice with breast tumor treated with endothelial cells by intravenous route. Results are mean \pm SEM of 10 measurements obtained from 10 individual mice. B) Graph shows tumor growth in mice bearing breast tumors treated with MSCs or endothelial cells by intra tumor route at time intervals after cell therapy. C) Graph shows the tumor growth in mice bearing breast tumors treated with MSCs or endothelial cells by intra venous route at time intervals after cell therapy. Each bar shows the mean \pm SD of 10 measurements from 10 mice. ${ }^{*}$ Sign shows $P<0.05$ significantly different from respective control. D) Images from tumors, T1 show a large tumor dissected from untreated mouse on day 5 weeks after tumor induction. T2 shows a smaller tumor obtained from stem cell-treated mice.

tumors (positive control) expressed relatively higher levels of VEGFR2. VEGFR2 expression at mRNA levels was markedly decreased $(\mathrm{P}<0.05)$ in animal group treated with endothelial cells (EC/I.T) by I.T route. However, the VEGFR2 expression in breast tumor prepared from other experimental groups was within the range of control group (Figure 8).

Table 2. Effects of stem cell therapy on pathological indices of breast tumors

\begin{tabular}{lcccccc}
\hline Group & Type of cell therapy & Type of injection & Nottingham grade & Focal necrosis & Vascular invasion & Tumor hemorrhage \\
\hline $\mathbf{1}$ (Control) & Only PBS & Intra tumor & III/III & +1 & Present & 0 \\
$\mathbf{2}$ & MSCs & Intra tumor & III/III & +3 & +3 & Absent \\
$\mathbf{3}$ & Endothelial cells & Intra tumor & III/III & +3 & Absent & +2 \\
$\mathbf{4}$ (Control) & Only PBS & Intra venous & III/III & +1 & Present & 0 \\
$\mathbf{5}$ & MSCs & Intra venous & III/III & +2 & Absent & +1 \\
$\mathbf{6}$ & Endothelial cells & Intra venous & III/III & +2 & Absent & +2 \\
\hline
\end{tabular}

The details about the experimental groups and tumor handling and processing for H\&E staining are as described in methods section. The data are from representative tumor samples of at least 3 mice/group. Wherever indicated MSCs means non-differentiated mesenchymal stromal cells derived from mice bone marrow. Endothelial cells are the cells obtained 5 days after inducing endothelial differentiation of MSCs. The method of scoring focal necrosis and tumor hemorrhage are as described under method's section. 

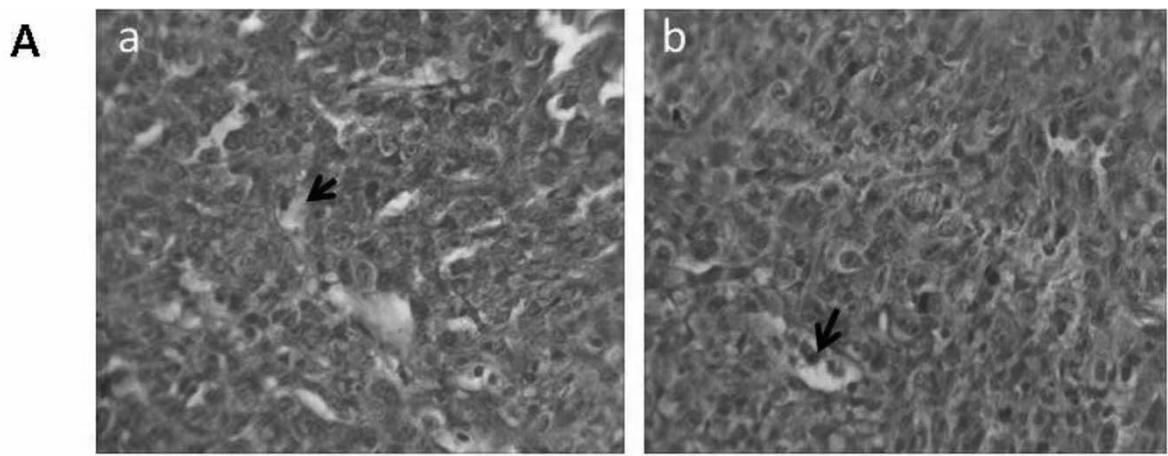

B
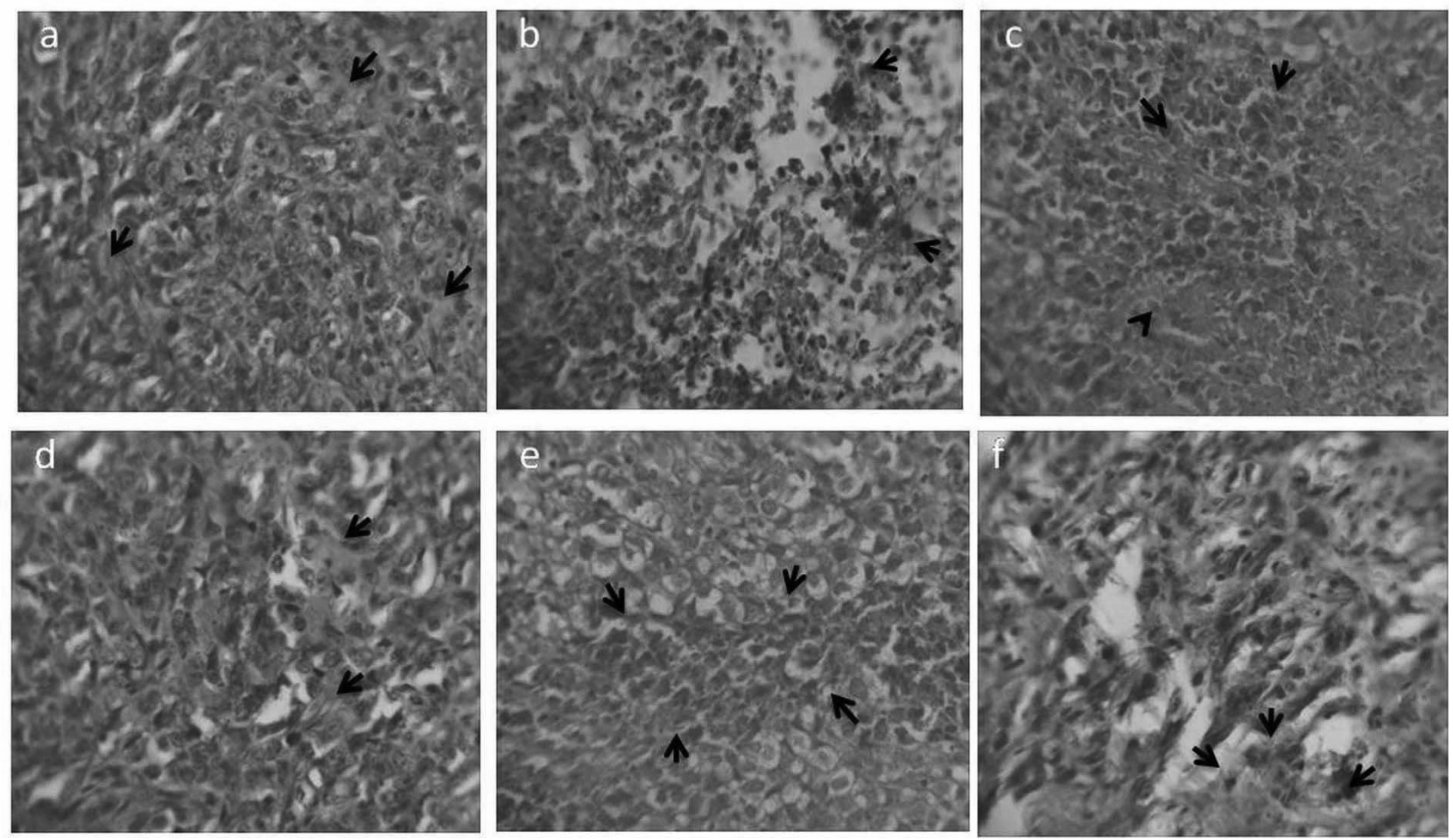

Figure 6. Histological changes in breast tumors obtained from mice treated with stromal cells: The tumor sections were stained with H\&E. A) Photomicrograph of breast tumor from controls show vascular invasion in (a) PBS/I.T group and (b) PBS/I.V group. B) Photomicrograph of breast tumor from all groups showing necrosis in breast tumor tissue of (a) PBS/I.T group, (b) mice treated I.T with MSCs, (c) mice treated I.T with MSCs (d) PBS/I.V group, (e) mice treated I.V with MSCs and (f) mice treated I.V with MSCs. Original magnification is $400 \times$.The complete data obtained from this experiment are summarized in Table 2.

\section{Discussion}

Investigations show that transplantation/introduction of endothelial cells derived from stromal cells can restore tissue vascularization after ischemic injury in limbs, retina and myocardium [38]. The incorporation of endothelial cells or their progenitor cells into newly sprouting blood vessels has been shown by imaging methods as well as expression of endothelial specific markers [39, 40]. However, the capacity of the stromal cells-derived endothelial cells to target abnormal angiogenesis within tumors is not well understood. The present study aimed to examine the effects of MSCs and endothelial-like cells de- rived from them on tumor growth and vessel density within tumors in a mouse model of breast cancer.

Our previous report shows that the endothelial-like cells derived from human bone marrow resemble endothelial cells which participate in capillary formation on extracellular matrix (ECM) in vitro. The endothelial cells were characterized by their morphological and molecular characteristics in capillary network formation [29]. The ability of endothelial-like cells to contribute in neo-vascularization was further confirmed in vivo in a SCID mouse model of angiogenesis [30].

Identification of endothelial cell lineage is often done by estimation of endothelial markers particularly VEGFR2. Ex- 
A

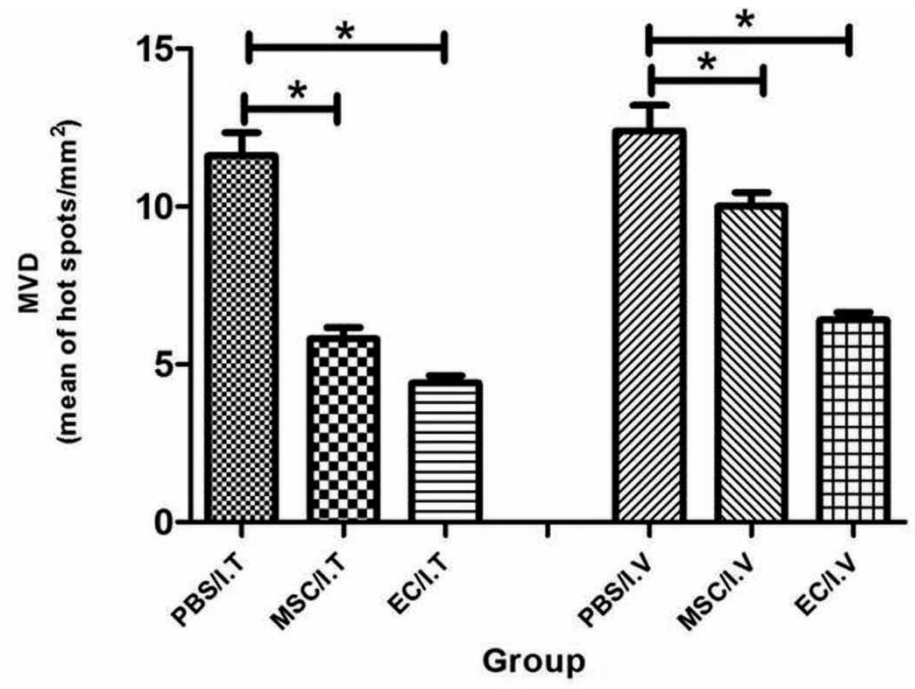

B
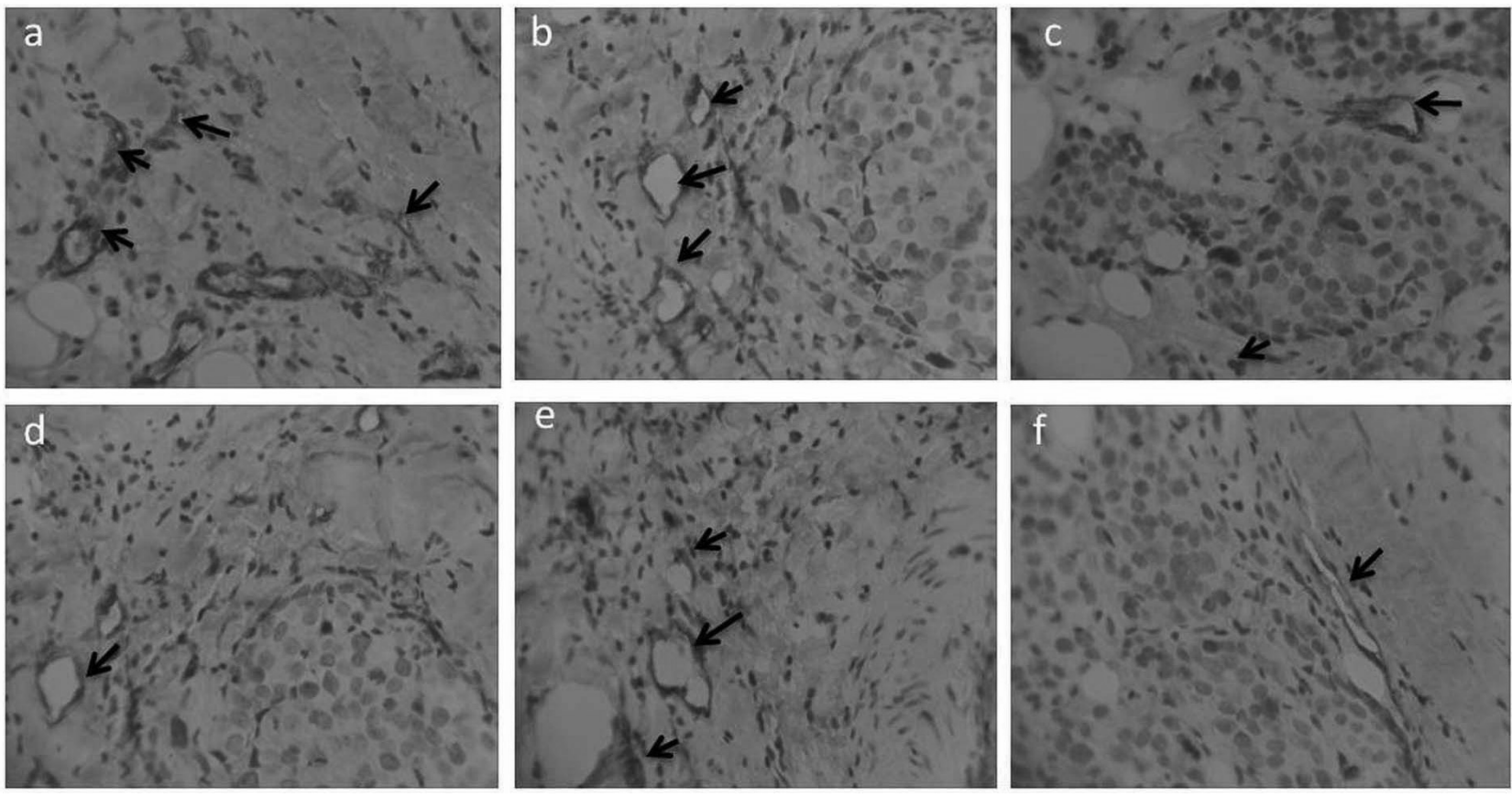

Figure 7. Effects of stem cell therapy on micro vessel density (MVD) in breast tissue (IHC): A) Graph compares MVD detected by IHC assay by using CD31 marker in breast tumor. The experimental groups are as described in Figure 5 legend. Values represent mean \pm SEM. ${ }^{\star}$ Sign indicates significant difference with $\mathrm{P}<0.05$ between treated and control groups. B) Section a-f show the localization of CD31 in breast tumors in mice treated with MSCs or endothelial cells. CD31 was localized using anti-CD31 antibody. Section a: Positive control animals (I.T-treated prepared in PBS). Section b: mice I.T injection of MSCs. Section c: Mice injected I.T with endothelial cells. Section d: Positive control mice bearing tumor treated I.V with PBS. Section e: Mice injected I.V injection of MSCs. Section f: Mice receive I.V injection of endothelial cells. Original magnification 400x. Arrows show endothelial cells expressing CD31.

pression of this specific marker was noticed in cells after five days of differentiation performed in presence of VEGF and IGF1. Approximately $60 \%$ of the differentiated cells expressed VEGFR2, which is known as an early and predominant biochemical marker expressed by endothelial cells, although at later stage other markers such as CD31, Tie-1, Tie-2, and VEcadherin were also detected during endothelial differentiation [41].
In spite of the experimental evidences showing anti-tumor effects of MSCs, there are reports showing pro-tumor action of MSC therapy. For instance, Liu et al., showed the expansion of breast cancer stem cell (CSC) population and acceleration of tumor growth following MSC treatment, suggesting the involvement of cytokine pathways [42].

Most of the reports on MSC therapy of breast cancer agree on the anti-tumor effects of these cells. It has been shown that 
I.V administration of MSCs can effectively inhibit tumor cell proliferation and inhibition of metastasis [19]. Also, it was reported that the MSCs isolated from human and rat umbilical cord could significantly suppress growth of breast cancer cells in vitro and in vivo [43-45].

There are a few reports dealing with stromal cell therapy by targeting angiogenesis mostly using MSCs to target vascular network in melanoma and brain tumors. In this connection Otsu et al. (2009) treated mouse model of melanoma with I.T administration of MSCs and proved the interaction of MSCs with neocapillary network in the tumors causing cytotoxicity and apoptosis of the tumor-associated endothelial cells [31]. Consistent with this, Pisati et al.(2007) showed that stromal cells derived from human skin administered to mice (human brain tumor model) was responsible for inhibition of tumor growth, reduction of tumor vessel density, and decrease of angiogenic sprouts [46].

The outcome of the MSC therapy varies depending on factors such as the source and type of stem cells, number of cells injected, route of administration, type of the experimental model and time of cell therapy. Perhaps, the MSCs are undifferentiated cells and the mechanisms of their action on tumors are not fully understood. Their indirect action could be assigned to their immunomodulatory properties when reach to tumor microenvironment. MSCs may also directly interact with cancer cells and tumor-associated cells [47].

The efficacy of stem cell therapy depends of the route of administration. In case of intra- tumor (I.T) administration of cells unlike infusion (I.V), the cells might interact with the target cells. Moreover, the cells given by I.T route will neither be entrapped in organs such as lungs, nor they challenge the systemic immune reactions [48-50].

In this study it was demonstrated that the stromal cells injected either by I.T or I.V could reach the tumor site. Appearance of GFP-labeled MSCs in tumors one week after administration resulted in decrease in tumor size, which probably affects tumor proliferation and progression.

The effect of I.V and I.T administrations of MSCs on breast tumor growth (in vivo animal model) showed that the I.T route is relatively more efficient in suppression of tumor growth. Accordingly, the endothelial cells derived from MSCs were relatively more effective in reducing breast tumor growth in mice compared to MSCs given either by I.T or I.V route. There are different stimuli which facilitate the recruitment of endothelial cells towards the tumor site. Pre-treatment of the stromal cells to growth factors such as, IGF1 during cell differentiation in the culture media can induce the expression of chemokine receptor type 4 (CXCR4) which is believed to play a major role in this process $[51,52]$.

The evidences presented in this study show the advantages of local delivery to tumors (I.T route) of stromal cells over the systemic delivery which can increase direct interaction of the cells with the vessel network. The efficiency of I.T administration of endothelial cells compared to MSCs in tumor suppression was also reflected in the rate of angiogenesis. This

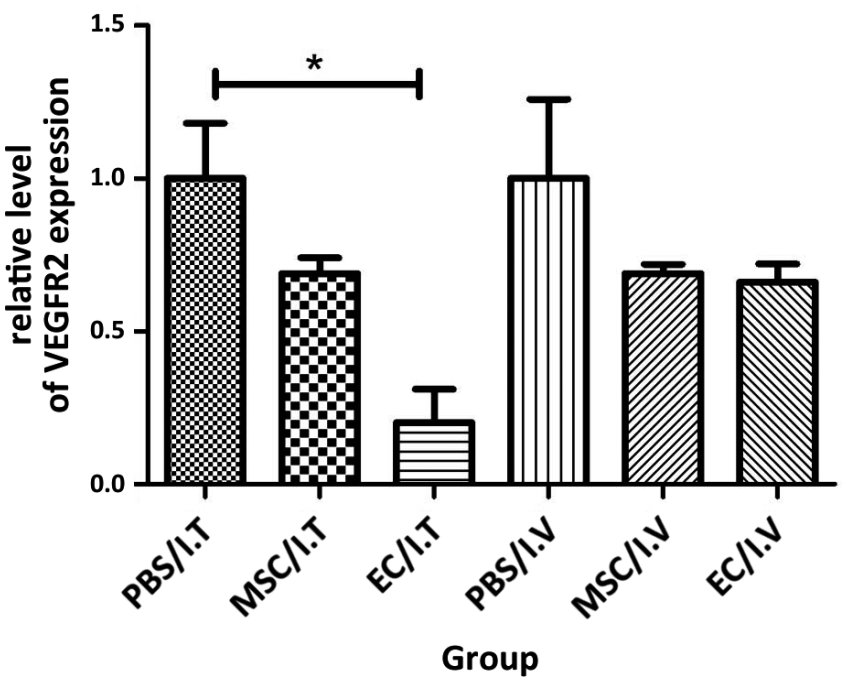

Figure 8. Expression of VEGFR2 in breast tumors in mice treated with mesenchymal stem cells or endothelial cells: VEGFR2 was quantitatively assayed in tumor preparation using real-time RT-PCR (QPCR). Experimental groups are as described in methods section as well in Figure 5 legend. VEGFR2 specific mRNA was estimated in relation to HPRT gene expression which is housekeeping gene. Values represent mean $\pm \mathrm{SD}$. * indicate significant difference between each treated group and control with $\mathbf{P}<0.05$.

was approved by showing that the MVD using CD31 expression (IHC) was more significantly reduced in mice treated with endothelial cells via I.T route. This data are supported by showing the correlation of MVD with tumor size and prognostic parameters reported in human infiltrative lobular and ductal breast carcinoma [53].

It was assumed that the abnormal angiogenesis in breast tumor can be targeted by endothelial-like cells derived from MSCs. Hence in the present study, breast tumors in mice were targeted with MSCs or endothelial cells differentiated from them with emphasis on abnormal vascular network as the target. The evidences presented here suggest that the relationship of the endothelial cells derived from MSCs with the tumor-endothelial cells is probably a competitive interaction. This competition is probably in favors of normal endothelial cells because the endothelial cells forming angiogenesis in tumor-associated blood vessels are considered cytogenetically abnormal [54].

It appears that the major part of the VEGFR2 expression in tumors is attributed to the tumor vascular network. This evidence was supported by detection of VEGFR2 expression in tumor tissues even 30 days after the cell therapy. The endothelial cells when injected I.T to mice could affect tumor-related VEGFR2 expression. Following transplantation of endothelial cells into breast tumor in mice (I.T) there was a significant decrease $(80 \%)$ in VEGFR2 expression in tumors as shown by QPCR technique (Figure 8). Down regulation of VEGFR2 in 
tumor tissue which was associated with suppression of tumor growth was confined to animals treated I.T with endothelial cells.

The tumor growth in different experimental groups measured by qualitative scoring was inversely related to tumor necrosis as determined by H\&E staining. A $53 \%$ decrease in tumor size in mice treated I.T with endothelial cells was associated with relatively higher scores of focal necrosis (Figure 5). Relatively higher score of focal necrosis was recorded in tumor samples of mice given I.V injection of MSCs or endothelial cells. This information further suggests that the endothelial cells injected directly into tumors can act more efficiently and selectively on angiogenesis as a target. Suppression of vascular invasion in case of stem-cell treated mice compared to untreated animals further supports the anti-tumor action of stromal cell in breast cancer.

It is concluded that breast tumor growth is suppressed following treatment with either MSCs or endothelial cells. The tumor retardation was observed in mice model regardless of the route of administration. However, it seems that the therapeutic effects of the stem cells were greater when given by I.T route. Furthermore, it appears that the performance of endothelial-like cells in controlling breast tumor is better through normalization of abnormal angiogenesis.

Acknowledgments: This study was financially supported by Tarbiat Modares University. This study has also been supported by NIMAD (National Institute for Medical Research Development), grant \#943791. This article is part of the PhD dissertation of Maryam Adelipour.

\section{References}

[1] HANAHAN D, WEINBERG RA. Hallmarks of cancer: the next generation. Cell 2011; 144: 646-674. http://dx.doi. org/10.1016/j.cell.2011.02.013

[2] ZIYAD S, IRUELA-ARISPE ML. Molecular mechanisms of tumor angiogenesis. Genes Cancer 2011; 2: 1085-1096. http:// dx.doi.org/10.1177/1947601911432334

[3] GOEL S, DUDA DG, XU L, MUNN LL, BOUCHER Y et al. Normalization of the vasculature for treatment of cancer and other diseases. Physiol Rev 2011; 91: 1071-1121. http://dx.doi. org/10.1152/physrev.00038.2010

[4] HUANG Y, GOEL S, DUDA DG, FUKUMURA D, JAIN RK. Vascular normalization as an emerging strategy to enhance cancer immunotherapy. Cancer Res 2013; 73: 2943-2948. http://dx.doi.org/10.1158/0008-5472.CAN-12-4354

[5] JAIN RK. Normalizing tumor microenvironment to treat cancer: bench to bedside to biomarkers. JCO 2013; 31: 2205-2218. http://dx.doi.org/10.1200/JCO.2012.46.3653

[6] MAGRINI E, VILLA A, ANGIOLINI F, DONI A, MAZZAROL $G$ et al. Endothelial deficiency of L1 reduces tumor angiogenesis and promotes vessel normalization. JCI 2014; 124: 4335-4350. http://dx.doi.org/10.1172/JCI70683

[7] MANN CD, NEAL CP, GARCEA G, MANSON MM, DENNISON AR et al. Prognostic molecular markers in hepatocellular carcinoma: a systematic review. EJC 2007; 43: 979-992. http:// dx.doi.org/10.1016/j.ejca.2007.01.004

[8] UZZAN B, NICOLAS P, CUCHERAT M, PERRET G-Y. Microvessel density as a prognostic factor in women with breast cancer a systematic review of the literature and metaanalysis. Cancer Res 2004; 64: 2941-2955. http://dx.doi. org/10.1158/0008-5472.CAN-03-1957

[9] URBICH C, DIMMELER S. Endothelial progenitor cells characterization and role in vascular biology. Circ Res 2004; 95: 343-353. http://dx.doi.org/10.1161/01. $\underline{\text { RES.0000137877.89448.78 }}$

[10] KUMAR S, GHELLAL A, LI C, BYRNE G, HABOUBI N et al. Breast carcinoma vascular density determined using CD105 antibody correlates with tumor prognosis. Cancer Res 1999; 59: 856-861.

[11] ZIBARA K, AWADA Z, DIB L, EL-SAGHIR J, AL-GHADBAN $S$ et al. Anti-angiogenesis therapy and gap junction inhibition reduce MDA-MB-231 breast cancer cell invasion and metastasis in vitro and in vivo. Sci Rep 2015; 5: 1-16. http://dx.doi.org/10.1038/srep12598

[12] GYORFFY S, PALMER K, PODOR TJ, HITT M, GAULDIE J. Combined treatment of a murine breast cancer model with type 5 adenovirus vectors expressing murine angiostatin and IL-12: a role for combined anti-angiogenesis and immunotherapy. The JI 2001; 166: 6212-6217. http://dx.doi. org/10.4049/jimmunol.166.10.6212

[13] LONGATTO FILHO A, LOPES JM, SCHMITT FC. Angiogenesis and breast cancer. J Oncol 2010; 2010: 1-7. http:// dx.doi.org/10.1155/2010/576384

[14] VASUDEV NS, REYNOLDS AR. Anti-angiogenic therapy for cancer: current progress, unresolved questions and future directions. Angiogenesis 2014; 17: 471-494. http://dx.doi. org/10.1007/s10456-014-9420-y

[15] SHOJAEI F. Anti-angiogenesis therapy in cancer: current challenges and future perspectives. Cancer lett 2012; 320 130-137. http://dx.doi.org/10.1016/j.canlet.2012.03.008

[16] MACKEY JR, KERBEL RS, GELMON KA, MCLEOD DM, CHIA SK et al. Controlling angiogenesis in breast cancer: a systematic review of anti-angiogenic trials. Cancer Treat Rev 2012; 38: 673-688. http://dx.doi.org/10.1016/j. ctrv.2011.12.002

[17] BEHDANI M, ZEINALI S, KHANAHMAD H, KARIMIPOUR M, ASADZADEH N et al. Generation and characterization of a functional Nanobody against the vascular endothelial growth factor receptor-2; angiogenesis cell receptor. Mol Immunol 2012; 50: 35-41. http://dx.doi. org/10.1016/j.molimm.2011.11.013

[18] MARTIN F, DWYER R, KELLY J, KHAN S, MURPHY J et al. Potential role of mesenchymal stem cells (MSCs) in the breast tumour microenvironment: stimulation of epithelial to mesenchymal transition (EMT). Breast Cancer Res Treat 2010; 124: 317-326. http://dx.doi.org/10.1007/s10549-0100734-1

[19] SUN B, ROH K-H, PARK J-R, LEE S-R, PARK S-B et al. Therapeutic potential of mesenchymal stromal cells in a mouse breast cancer metastasis model. Cytotherapy 2009; 11 : 289-298. http://dx.doi.org/10.1080/14653240902807026 
[20] DAI L-J, MONIRI MR, ZENG Z-R, ZHOU JX, RAYAT J et al. Potential implications of mesenchymal stem cells in cancer therapy. Cancer Lett 2011; 305: 8-20. http://dx.doi. org/10.1016/j.canlet.2011.02.012

[21] BLISS TM, ANDRES RH, STEINBERG GK. Optimizing the success of cell transplantation therapy for stroke. Neurobiol Dis 2010; 37: 275-283. http://dx.doi.org/10.1016/j. nbd.2009.10.003

[22] HAYASHI J, TAKAGI Y, FUKUDA H, IMAZATO T, NISHIMURA $M$ et al. Primate embryonic stem cell-derived neuronal progenitors transplanted into ischemic brain. J Cereb Blood Flow Metab 2006; 26: 906-914. http://dx.doi. org/10.1038/sj.jcbfm. 9600247

[23] VIJA L, FARGE D, GAUTIER J-F, VEXIAU P, DUMITRACHE C et al. Mesenchymal stem cells: Stem cell therapy perspectives for type 1 diabetes. Diabetes Metab 2009; 35: 85-93. http:// dx.doi.org/10.1016/j.diabet.2008.10.003

[24] LEE RH, SEO MJ, REGER RL, SPEES JL, PULIN AA et al. Multipotent stromal cells from human marrow home to and promote repair of pancreatic islets and renal glomeruli in diabetic NOD/scid mice. Proc Natl Acad Sci U S A 2006; 103: 17438-17443. http://dx.doi.org/10.1073/pnas.0608249103

[25] LE BLANC K, RINGDEN O. Immunobiology of human mesenchymal stem cells and future use in hematopoietic stem cell transplantation. Biol Blood Marrow Transplant 2005; 11: 321-334. http://dx.doi.org/10.1016/j.bbmt.2005.01.005

[26] KARUSSIS D, KARAGEORGIOU C, VAKNIN-DEMBINSKY A, GOWDA-KURKALLI B, GOMORI JM et al. Safety and immunological effects of mesenchymal stem cell transplantation in patients with multiple sclerosis and amyotrophic lateral sclerosis. Arch Neurol 2010; 67: 1187-1194. http://dx.doi. org/10.1001/archneurol.2010.248

[27] TSUKADA S, KWON S-M, MATSUDA T, JUNG S-Y, LEE J-H et al. Identification of mouse colony-forming endothelial progenitor cells for postnatal neovascularization: a novel insight highlighted by new mouse colony-forming assay. Stem Cell Res Ther 2013; 4: 1-13. http://dx.doi.org/10.1186/scrt168

[28] ZHU XY, URBIETA冈CACERES V, KRIER JD, TEXTOR SC, LERMAN A et al. Mesenchymal stem cells and endothelial progenitor cells decrease renal injury in experimental swine renal artery stenosis through different mechanisms. Stem Cells 2013; 31: 117-125. http://dx.doi.org/10.1002/stem.1263

[29] JAZAYERI M, ALLAMEH A, SOLEIMANI M, JAZAYERI SH, PIRYAEI A et al. Molecular and ultrastructural characterization of endothelial cells differentiated from human bone marrow mesenchymal stem cells. Cell Biol Int 2008; 32: 1183-1192. http://dx.doi.org/10.1016/j.cellbi.2008.07.020

[30] ALLAMEH A, JAZAYERI M, ADELIPOUR M. In vivo vascularization of endothelial cells derived from bone marrow mesenchymal stem cells in SCID mouse model. Cell J 2016; 18: 179-188.

[31] OTSU K, DAS S, HOUSER SD, QUADRI SK, BHATTACHARYA $S$ et al. Concentration-dependent inhibition of angiogenesis by mesenchymal stem cells. Blood 2009; 113: 4197-4205. http://dx.doi.org/10.1182/blood-2008-09-176198

[32] NOORI S, HASSAN ZM. Dihydroartemisinin shift the immune response towards Th1, inhibit the tumor growth in vitro and in vivo. Cell Immunol 2011; 271: 67-72. http://dx.doi. org/10.1016/j.cellimm.2011.06.008

[33] SOLEIMANI M, NADRI S. A protocol for isolation and culture of mesenchymal stem cells from mouse bone marrow. Nat Protoc 2009; 4: 102-106. http://dx.doi.org/10.1038/ nprot.2008.221

[34] SOLALI S, KAVIANI S, SOLEIMANI M, ZONUBI Z. Isolation and characterization of mesenchymal stem cells derived from adipose tissue. Faslnamahi Kumish 2015; 16: 505-511.

[35] KENARKOOHI A, SOLEIMANI M, BAMDAD T, SOLEIMANJAHI H, ESTIRI $\mathrm{H}$ et al. Efficient Lentiviral Transduction of Adipose Tissue-Derived Mouse Mesenchymal Stem Cells and Assessment of Their Penetration in Female Mice Cervical Tumor Model. Iran J Cancer Prev 2014; 7: 225-231.

[36] SANCEAU J, POUPON M-F, DELATTRE O, SASTRE-GARAU X, WIETZERBIN J. Strong inhibition of Ewing tumor xenograft growth by combination of human interferon-alpha or interferon-beta with ifosfamide. Oncogene 2002; 21 : 7700-7709. http://dx.doi.org/10.1038/sj.onc.1205881

[37] MUHAMMADNEJAD S, MUHAMMADNEJAD A, HADDADI M, OGHABIAN M-A, MOHAGHEGHI M-A et al. Correlation of microvessel density with nuclear pleomorphism, mitotic count and vascular invasion in breast and prostate cancers at preclinical and clinical levels. Asian Pac J Cancer Prev 2012; 14: 63-68. http://dx.doi.org/10.7314/ APJCP.2013.14.1.63

[38] RAFII S, LYDEN D. Therapeutic stem and progenitor cell transplantation for organ vascularization and regeneration. Nat Med 2003; 9: 702-712. http://dx.doi.org/10.1038/ nm0603-702

[39] ASAHARA T, MUROHARA T, SULLIVAN A, SILVER M, VAN DER ZEE $\mathrm{R}$ et al. Isolation of putative progenitor endothelial cells for angiogenesis. Science 1997; 275: 964-966. http://dx.doi.org/10.1126/science.275.5302.964

[40] ARBAB AS, FRENKEL V, PANDIT SD, ANDERSON SA, YOCUM GT et al. Magnetic resonance imaging and confocal microscopy studies of magnetically labeled endothelial progenitor cells trafficking to sites of tumor angiogenesis. Stem Cells 2006; 24: 671-678. http://dx.doi.org/10.1634/ stemcells.2005-0017

[41] VITTET D, PRANDINI M-H, BERTHIER R, SCHWEITZER A, MARTIN-SISTERON H et al. Embryonic stem cells differentiate in vitro to endothelial cells through successive maturation steps. Blood 1996; 88: 3424-3431.

[42] LIU S, GINESTIER C, OU SJ, CLOUTHIER SG, PATEL SH et al. Breast cancer stem cells are regulated by mesenchymal stem cells through cytokine networks. Cancer Res 2011; 71: 614-624. http://dx.doi.org/10.1158/0008-5472.CAN-10$\underline{0538}$

[43] OHTA N, ISHIGURO S, KAWABATA A, UPPALAPATI D, PYLE $M$ et al. Human umbilical cord matrix mesenchymal stem cells suppress the growth of breast cancer by expression of tumor suppressor genes. PloS one 2015; 10: 1-17. http:// dx.doi.org/10.1371/journal.pone.0123756

[44] GANTA C, AYUZAWA R, RACHAKATLA R, PYLE M, ANDREWS G et al. Rat Umbilical Cord Stem Cells Completely 
Abolish Rat Mammary Carcinomas with No Evidence of Metastasis or Recurrence 100 Days Post-Tumor Cell Inoculation. Cancer Res 2009; 69: 1815-1820. http://dx.doi. org/10.1158/0008-5472.CAN-08-2750

[45] AYUZAWA R, DOI C, RACHAKATLA RS, PYLE MM, MAURYA DK et al. Naive human umbilical cord matrix derived stem cells significantly attenuate growth of human breast cancer cells in vitro and in vivo. Cancer Lett 2009; 280: 31-37. http://dx.doi.org/10.1016/j.canlet.2009.02.011

[46] PISATI F, BELICCHI M, ACERBI F, MARCHESI C, GIUSSANI C et al. Effect of human skin-derived stem cells on vessel architecture, tumor growth, and tumor invasion in brain tumor animal models. Cancer Res 2007; 67: 3054-3063. http://dx.doi.org/10.1158/0008-5472.CAN-06-1384

[47] STUCKEY DW, SHAH K. Stem cell-based therapies for cancer treatment: separating hope from hype. Nat Rev Cancer 2014; 14: 683-691. http://dx.doi.org/10.1038/nrc3798

[48] NYSTEDT J, ANDERSON H, TIKKANEN J, PIETILÄ M, HIRVONEN T et al. Cell surface structures influence lung clearance rate of systemically infused mesenchymal stromal cells. Stem Cells 2013; 31: 317-326. http://dx.doi.org/10.1002/stem.1271

[49] SCHREPFER S, DEUSE T, REICHENSPURNER H, FISCHBEIN M, ROBBINS $\mathrm{R}$ et al. Stem cell transplantation: the lung barrier. Transplant Proc 2007; 39: 573-576. http://dx.doi. org/10.1016/j.transproceed.2006.12.019
[50] FISCHER UM, HARTING MT, JIMENEZ F, MONZONPOSADAS WO, XUE $\mathrm{H}$ et al. Pulmonary passage is a major obstacle for intravenous stem cell delivery: the pulmonary first-pass effect. Stem Cells Dev 2009; 18: 683-692. http:// dx.doi.org/10.1089/scd.2008.0253

[51] LI Y, YU X, LIN S, LI X, ZHANG S et al. Insulin-like growth factor 1 enhances the migratory capacity of mesenchymal stem cells. Biochem Biophys Res Commun 2007; 356: 780-784. http://dx.doi.org/10.1016/j.bbrc.2007.03.049

[52] GUO J, LIN G, BAO C, HU Z, CHU H et al. Insulin-like growth factor 1 improves the efficacy of mesenchymal stem cells transplantation in a rat model of myocardial infarction. J Biomed Sci 2008; 15: 89-97. http://dx.doi.org/10.1007/ s11373-007-9207-x

[53] BOLAT F, KAYASELCUK F, NURSAL T, YAGMURDUR $\mathrm{M}, \mathrm{BAL} \mathrm{N}$ et al. Microvessel density, VEGF expression, and tumor-associated macrophages in breast tumors: correlations with prognostic parameters. J Exp Clin Cancer Res 2006; 14: 365-372.

[54] HIDA K, HIDA Y, SHINDOH M. Understanding tumor endothelial cell abnormalities to develop ideal anti-angiogenic therapies. Cancer Sci 2008; 99: 459-466. http://dx.doi. org/10.1111/j.1349-7006.2007.00704.x 